\title{
X-Ray Diffraction, Electron Paramagnetic Resonance and Optical Absorption Study of Bauxite
}

\author{
Tanguturi Ravindra Reddy¹, Krishnan Thyagarajan², Ovidio Almanza Montero ${ }^{3}$, \\ Sanapa Reddy Lakshmi Reddy ${ }^{*}$, Tamio Endo ${ }^{4}$ \\ ${ }^{1}$ Department of Physics, Sri Venkateswara Degree College, Kadapa, India \\ ${ }^{2}$ Department of Physics, Jawaharlal Nehru Technological University, College of Engineering, Pulivendla, India \\ ${ }^{3}$ Department of Physics, Universidad Nacional de Colombia, Bogota, Colombia \\ ${ }^{4}$ Graduate School of Engineering, Mie University, Tsu, Mie, Japan \\ Email: ${ }^{\text {drslreddy in@yahoo.com }}$
}

Received 20 November 2013; revised 30 December 2013; accepted 7 January 2014

Copyright (C) 2014 by authors and Scientific Research Publishing Inc.

This work is licensed under the Creative Commons Attribution International License (CC BY).

http://creativecommons.org/licenses/by/4.0/

(c) $\underset{\mathrm{EY}}{\mathrm{B}}$ Open Access

\section{Abstract}

The bauxite mineral obtained from Araku, Vishakapatnam district of Andhra Pradesh, India is used in the present work. Structural characterization was performed by X-ray diffraction (XRD). The mineral was found to be gibbsite in phase. The transitional metal ions present were investigated using electron paramagnetic resonance (EPR) and optical absorption spectra. The EPR results suggest that $\mathrm{Fe}^{3+}$ has replaced $\mathrm{Al}^{3+}$ in the unit cell of bauxite. The optical absorption spectrum is due to $\mathrm{Fe}^{3+}$ which indicates that it is in distorted octahedral environment. The near-infrared (NIR) spectrum is due to water fundamentals and combination overtones, which confirm the formula of the compound. The impurities in the mineral are identified using spectroscopic techniques.

\section{Keywords}

Bauxite; Gibbsite; X-Ray Diffraction (XRD); Electron Paramagnetic; Electron Paramagnetic Resonance; Optical Absorption Spectra; $\mathrm{Fe}^{3+}$; Water Fundamentals

\section{Introduction}

Bauxite is an aluminium ore. It is clay like compound. The most common impurity in the bauxite is the iron in *Corresponding author.

How to cite this paper: Reddy, T.R., Thyagarajan, K., Montero, O.A., Reddy, S.L. and Endo, T. (2014) X-Ray Diffraction, Electron Paramagnetic Resonance and Optical Absorption Study of Bauxite. Journal of Minerals and Materials Characterization and Engineering, 2, 114-120. http://dx.doi.org/10.4236/immce.2014.22015 
ferric state that results from the replacement of aluminium in the crystalline matrix. Gibbsite, disapore and boehmite are the three hydrates of alumina. Often gibbsite $\left(\mathrm{Al}_{2} \mathrm{O}_{3} \cdot 3 \mathrm{H}_{2} \mathrm{O}\right)$ is the predominant mineral in bauxite. Further gibbsite is a stable form of the bauxite at lower temperatures, whereas at higher temperatures, disapore or boehmite is the most stable phase. In gibbsite, the fundamental unit of the structure is a layer of $\mathrm{Al}^{3+}$ ions which are octahedrally coordinated with oxygens. All of the coordinated sites between the oxygen layers are occupied by cations. The layers may be regarded as built of octahedra linked laterally by sharing edges and network formed becomes an orthogonal structure. The structure of gibbsite is a distorted octahedron resulting in orthogonal cell with $\mathrm{a}=8.64 \AA, \mathrm{b}=5.07 \AA$ and $\mathrm{c}=9.72 \AA$ [1] [2]. Vibrational spectroscopic techniques have been used in the characterization of bauxite- and seawater-neutralized bauxite residues [3]. The studies indicate that the ferric ion in bauxite residue could be identified by its characteristic NIR spectra.

Alumina $\left(\mathrm{Al}_{2} \mathrm{O}_{3}\right)$ is prepared from raw bauxite by a hydrometallurgical technique known as "Bayer process". Bauxite is leached under high temperature and pressure with sodium hydroxide solution. From the solution, the insoluble material also termed as red mud is separated. The precipitate is aluminium hydroxide then it is finally calcined to alumina. After that, alumina is subjected to electrolytic reduction to obtain pure aluminum. It is important to know the composition and mineralogy of bauxite deposits in order to evaluate the processability of the material. Detailed mineral characterization of bauxites can lead to the creation of effective processing options and can also be used to evaluate bauxite beneficiation techniques for ore quality enhancement before processing. The compositional analysis of different localities' bauxite sample had been reported and is given in Table 1.

About $10 \mathrm{mg}$ of bauxite sample was taken in an agate pestle and mortar. The mineral sample is finely ground like a face powder. The powdered sample is used in the present study for different spectral techniques. In the present study, we used pale yellow coloured bauxite originated from Araku, Vishakapatnam district of Andhra Pradesh, India and studied its structural properties including particle size and nature of metal-oxygen bond using $\mathrm{X}$-ray diffraction (XRD), electron paramagnetic resonance (EPR), optical absorption and near-infrared (NIR) spectroscopic methods.

\section{Characterization Techniques}

The X-ray powder diffraction pattern of the bauxite was recorded in reflection geometry on a Philips X-ray diffractometer operating at $30 \mathrm{~mA}, 40 \mathrm{kV}$ using a $\mathrm{Cu}-\mathrm{K} \alpha(\lambda=1.54060 \AA)$ source at $25^{\circ} \mathrm{C}$ and the instrument was operated in the range of $10^{\circ}-75^{\circ}$. Data were collected using a continuous scan rate which was then refined into $2 \theta$ of $0.02^{\circ}$ per step.

EPR spectra of powdered bauxite sample was recorded at room temperature using a JEOL JES TE100 ESR spectrometer operated at the X-band frequency $(v=9.31929 \mathrm{GHz})$ with a $100 \mathrm{kHz}$ field modulation to obtain the first derivative EPR spectrum. DPPH (2,2-diphenyl-1-picrylhydrazyl) with a $g$ factor value of 2.0036 was used as a standard for the calculation of the $g$ factor.

An optical absorption spectrum of the mineral sample in a mull form was recorded at room temperature on a Carey 5E UV-Vis-NIR spectrophotometer in the range of 200 - $2500 \mathrm{~nm}$.

Band component analysis was performed using the Jandel "PEAKFIT" software package, which enabled the type of fitting functions to be selected and specific parameters to be fixed. Band fitting was conducted using a Lorentz-Gauss cross product function with a minimum number of component bands during the fitting process. The Lorentz-Gauss ratio was maintained at values greater than 0.7 , and fitting was performed until reproducible results were obtained with squared correlations of $r^{2}$ greater than 0.9975 .

Table 1. Chemical analysis of raw bauxite (wt\%).

\begin{tabular}{|c|c|c|c|c|c|}
\hline & \multicolumn{2}{|c|}{ Gujarat, India } & \multirow{2}{*}{$\begin{array}{c}\text { Australia } \\
\text { [5] }\end{array}$} & \multirow{2}{*}{$\begin{array}{c}\text { Visakhapatnam India } \\
{[6]}\end{array}$} & \multirow{2}{*}{ Present work } \\
\hline & & & & & \\
\hline $\mathrm{Al}_{2} \mathrm{O}_{3}$ & 84.58 & 79.53 & 15.0 & 47.75 & 53.4 \\
\hline $\mathrm{SiO}_{2}$ & 5.08 & 6.54 & 5.0 & 3.30 & 3.46 \\
\hline $\mathrm{TiO}_{2}$ & 4.52 & 4.58 & 4.5 & 3.14 & 3.89 \\
\hline $\mathrm{Fe}_{2} \mathrm{O}_{3}$ & 5.01 & 6.90 & 56.0 & 23.89 & 12.8 \\
\hline $\mathrm{CaO}$ & 0.81 & 2.44 & 1.25 & & 1.89 \\
\hline
\end{tabular}




\section{Results and Discussion}

\subsection{XRD Results}

Figure 1 presents the XRD pattern of the bauxite sample recorded on the Philips diffractrometer at $25^{\circ} \mathrm{C}$. Peaks were characterized using the Scherrer formula. The peaks were very sharp, indicating good crystallinity of the compound. The list of X-ray peaks of the bauxite sample is presented in Figure 1. The indexing of diffraction lines from various planes was similar to reported JCPDS file no 15-0776 [4]. Phase analysis study indicates that the major crystalline phase is gibbsite with a small amount of boehmite. The unit cell constants obtained from these peaks were $\mathrm{a}=8.75 \AA, \mathrm{b}=5.075 \AA$ and $\mathrm{c}=9.65 \AA$. Thus, the phase is a gibbsite. These values are similar to those reported for gibbsite mineral [7]. These results confirm that the mineral adopts a distorted octahedral rhombic structure. These values are similar to those reported for gibbsite mineral [7]. The X-ray density $d_{x}$ was calculated using the formula

$$
d_{x}=\frac{Z M}{N V},
$$

where $Z=8$ (number of molecules in a unit cell of gibbsite phase of the bauxite lattice), $M$ is the molecular mass of the gibbsite ( $155.964 \mathrm{~g} / \mathrm{mol}), N$ is Avogadro's number and $V$ is the lattice volume of the sample [8]. The calculated X-ray density was $4.83 \times 10^{3} \mathrm{~kg} / \mathrm{mm}^{3}$. The percentage porosity of sample was calculated using the relation,

$$
\rho=\left(1-\frac{d}{d_{x}}\right) 100
$$

with $d$ being the bulk density of the material (for gibbsite, $d=3.55 \mathrm{~g} / \mathrm{cm}^{3}$ ) [9]. The calculated value of the percentage porosity was 27 . The particle size of the compound is evaluated

$$
D_{(h k l)}=\frac{0.9 \lambda}{\beta_{1 / 2} \cos \theta} .
$$

where $D$ is the average particle size of the crystal, $\theta$ is the corresponding Bragg angle, $\lambda$ is the wavelength of incident X-ray, $\beta_{\frac{1}{2}}$ is the full width at half the maximum (FWHM) height of the peak. The particle size of the crystal, calculated by XRD was $70 \mathrm{~nm}$.

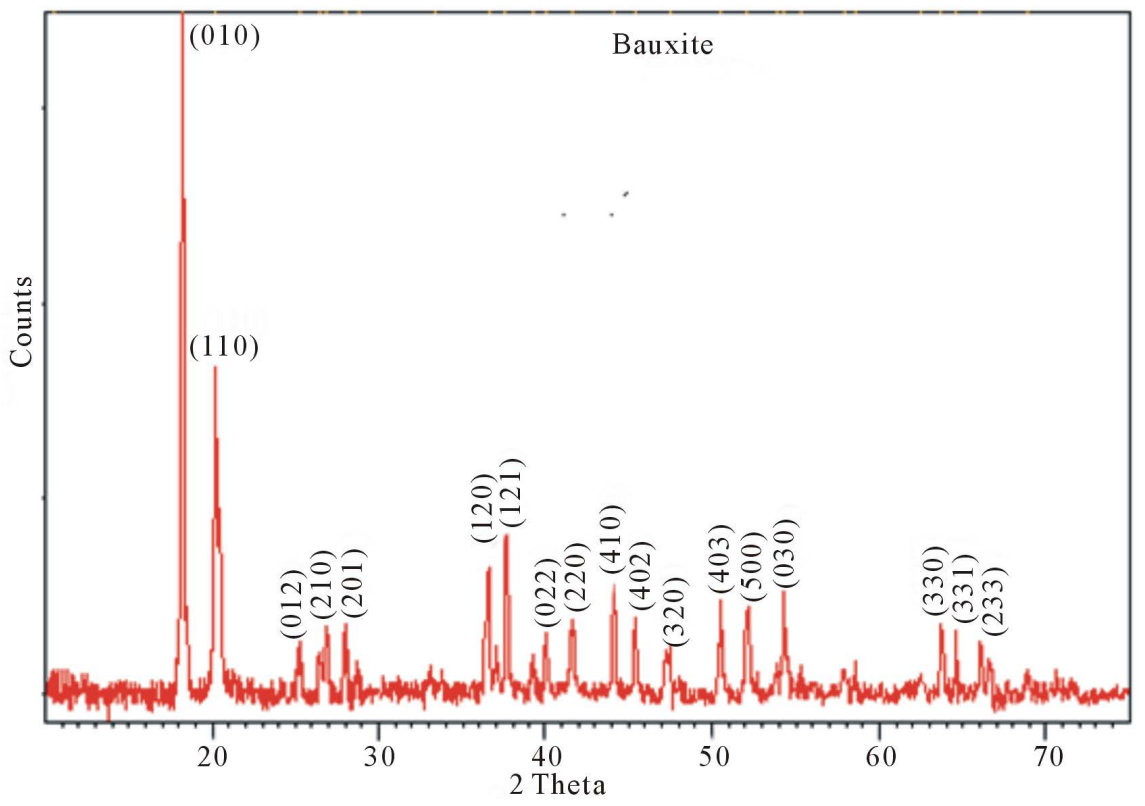

Figure 1. XRD spectrum of bauxite (gibbsite phase) at room temperature. 


\subsection{EPR Spectral Analysis}

EPR measurements are useful for obtaining information related to the location of the transitional metal ion impurities within the lattice of the natural bauxite sample. Figure 2 shows the spectrum of the powdered bauxite (gibbsite phase) at room temperature. It shows a large number of resonances. The $g$ values of different lines are indicated in the figure. These can be explained by considering charge compensating vacancies in the lattice, when $\mathrm{Fe}^{3+}$ is substituted for $\mathrm{Al}^{3+}$, it creates a low symmetry crystal field which is further distorted because of the strong tetragonal crystal field of $\mathrm{Fe}^{3+}$ ion. Hence, one can expect resonances from all the three Kramers doublets $| \pm 5 / 2\rangle,| \pm 3 / 2\rangle$ and $| \pm 1 / 2\rangle$. If the lowest doublet is populated, $g$ values are obtained ranging from 0 to 9 [10] [11]. If the middle doublet is populated gives $\mathrm{g}$ is 4.30 and if the third doublet is populated $\mathrm{g}$ values are 2/7 and 30/7 [10] [11]. A few systems are known which show resonances from all the three Kramers doublets [10] [11]. Accordingly, the EPR spectrum of the bauxite (gibbsite phase) shows with $g$ factors ranging from 8.3 to 2.1 due to $\mathrm{Fe}^{3+}$ impurity.

\subsection{Optical Absorption Spectral Results}

Optical absorption spectrum of bauxite is shown in Figure 3 from $200-2500 \mathrm{~nm}$ at RT. It consists of bands at $36,900 \mathrm{~cm}^{-1}$ (271 nm), 31,745 cm $\mathrm{cm}^{-1}$ (318 nm), 20,000 cm $\mathrm{cm}^{-1}(500 \mathrm{~nm}), 18,450 \mathrm{~cm}^{-1}(542 \mathrm{~nm}), 13,700 \mathrm{~cm}^{-1}(730$ $\mathrm{nm}), 12,790 \mathrm{~cm}^{-1}(782 \mathrm{~nm}), 12,300 \mathrm{~cm}^{-1}(813 \mathrm{~nm})$ and $12,300 \mathrm{~cm}^{-1}(813 \mathrm{~nm}) \mathrm{cm}^{-1}$ in the UV-Vis region. A band observed at $12,300 \mathrm{~cm}^{-1}$ with two component bands at 12,790 and $13,700 \mathrm{~cm}^{-1}$ is assigned to the transition ${ }^{6} \mathrm{~A}_{1 \mathrm{~g}}(\mathrm{~S}) \rightarrow{ }^{4} \mathrm{~T}_{1 \mathrm{~g}}(\mathrm{G})$ whereas the band at $18,450 \mathrm{~cm}^{-1}$ is assigned to ${ }^{4} \mathrm{~T}_{1 \mathrm{~g}}(\mathrm{G})$ transition for Fe(III). The band at $20,000 \mathrm{~cm}^{-1}$ is assigned to ${ }^{4} \mathrm{E}(\mathrm{G})$ transition in the present compound. These three bands are characteristic of $\mathrm{Fe}(\mathrm{III})$ ion occupying in distorted octahedral symmetry in the bauxite.

Assignment of each band to an appropriate electronic transition is difficult due to complexity of the transitions and multiplicity and distortions of the sites occupied by the transition metal ion. Therefore, Tanabe-Sugano diagram of $\mathrm{d}^{5}$ configuration is used to assign the transitions of the other bands [12]. The energy matrices of $\mathrm{d}^{5}$ configuration were solved for different values of Dq, B and C. The parameters that give good fit to the experimental data is $\mathrm{Dq}=842 \mathrm{~cm}^{-1}, \mathrm{~B}=600 \mathrm{~cm}^{-1}$ and $\mathrm{C}=2450 \mathrm{~cm}^{-1}$ and are presented in Table 2.

Also the bauxite spectrum shows the bands at $8285(1207 \mathrm{~nm}), 6770$ (1477 nm), 6345 (1576 nm), 5820 (1719 $\mathrm{nm}), 5675(1762 \mathrm{~nm}), 5170(1935 \mathrm{~nm}), 4740(2110 \mathrm{~nm}), 4400(2275 \mathrm{~nm}), 4330(2310 \mathrm{~nm}), 4260$ (2348 nm), $4190(2386 \mathrm{~nm})$ and $4050(2471 \mathrm{~nm}) \mathrm{cm}^{-1}$ in the NIR region. These are analysed as follows:

Water has $\mathrm{C}_{2 \mathrm{~V}}$ symmetry. It gives three fundamental modes. They are $v_{1}, v_{2}$ and $v_{3}$. $v_{1}$ represents symmetric $\mathrm{OH}$ stretch, $v_{2}$ the asymmetric $\mathrm{OH}$ stretch and $v_{3}$ the H-O-H bend respectively. In vapour phase $v_{1}$, $v_{2}$ and $v_{3}$ occur at 3652, 1595 and $3756 \mathrm{~cm}^{-1}$ respectively [13].

The first overtones of the $\mathrm{OH}$ stretching of the vibrations appear in the region 1300 - $1800 \mathrm{~nm}$. The sample

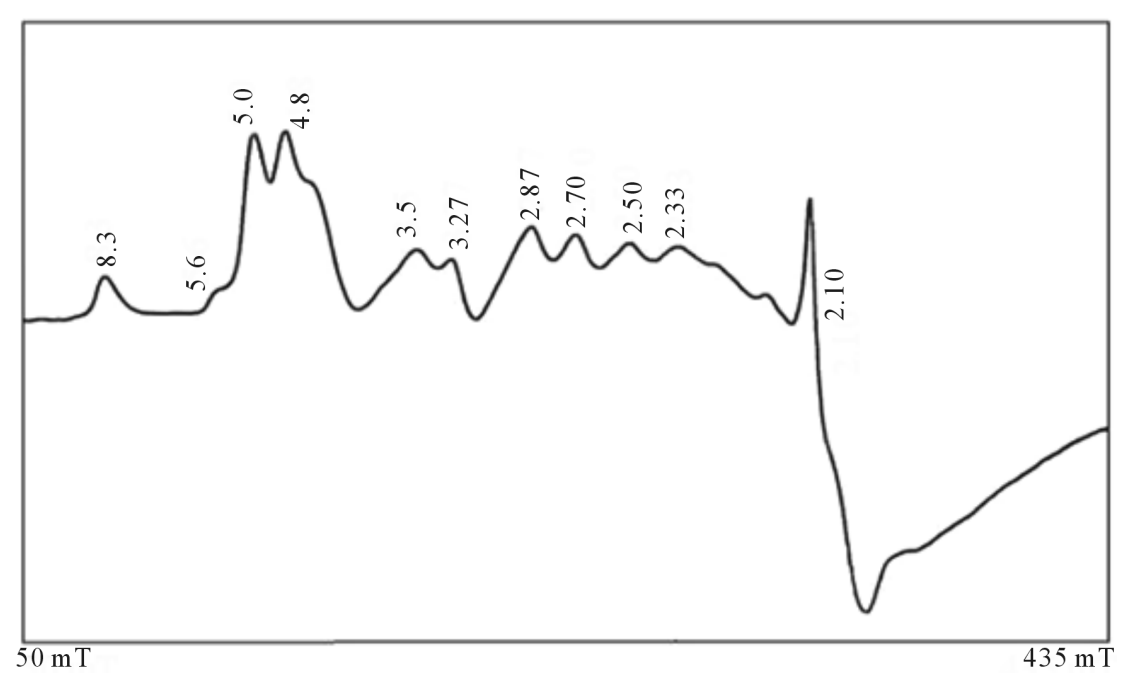

Figure 2. Room temperature EPR spectrum of bauxite (gibbsite phase) ( $v=9.31929$ $\mathrm{GHz})$. 


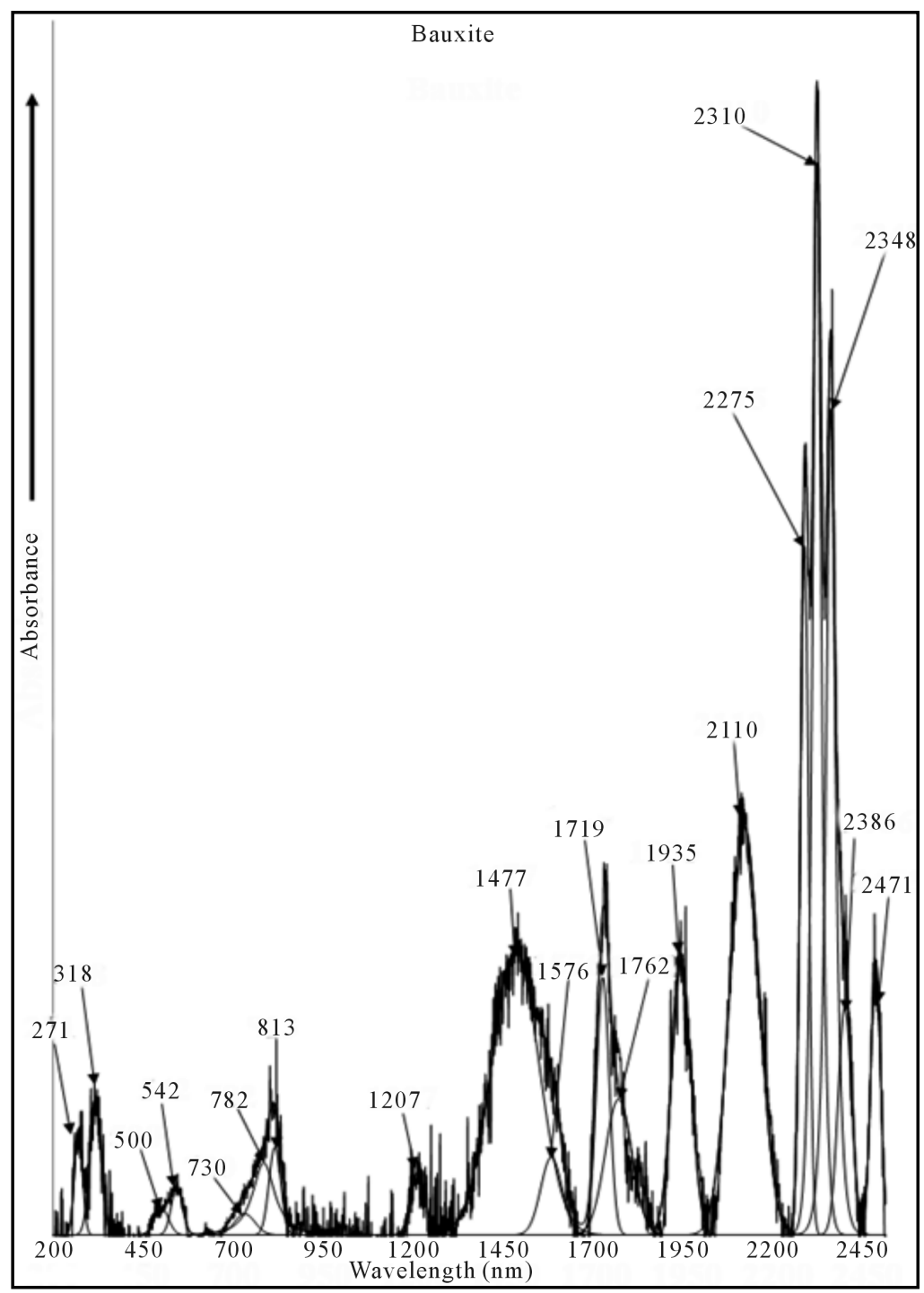

Figure 3. Room temperature optical absorption spectrum of bauxite (gibbsite).

Table 2. Band headed data with assignments for Fe(III) in bauxite (gibbsite phase). Dq $=842 \mathrm{~cm}^{-1}, \mathrm{~B}=600 \mathrm{~cm}^{-1}$ and $\mathrm{C}=$ $2450 \mathrm{~cm}^{-1}$.

\begin{tabular}{cccc}
\hline \multirow{2}{*}{ Wave length $(\mathrm{nm})$} & \multicolumn{2}{c}{ Wave number $\left(\mathrm{cm}^{-1}\right)$} & Transitions from ${ }^{6} \mathrm{~A}_{1 \mathrm{~g}}(\mathrm{~S})$ \\
\cline { 2 - 4 } 813 & Observed & Calculated & \\
782 & 12,300 & 12,796 & ${ }^{4} \mathrm{~T}_{1 \mathrm{~g}}(\mathrm{G})$ \\
730 & 12,790 & & \\
542 & 13,700 & 16,529 & ${ }^{4} \mathrm{~T}_{2 \mathrm{~g}}(\mathrm{G})$ \\
500 & 18,450 & 20,050 & ${ }^{4} \mathrm{E}_{\mathrm{g}}(\mathrm{G})$ \\
318 & 20,000 & 31,430 & ${ }^{4} \mathrm{~A}_{1 \mathrm{~g}}(\mathrm{G})$ \\
271 & 31,745 & 36,332 & ${ }^{4} \mathrm{~T}_{2 \mathrm{~g}}(\mathrm{~F})$ \\
\hline
\end{tabular}

shows a maximum intensity broad band centered at $6770 \mathrm{~cm}^{-1}$ and a weak band at $6345 \mathrm{~cm}^{-1}$. The complexity may be attributed to the combination of fundamental $\mathrm{OH}$ stretching and metal-OH deformation modes. 
In the NIR, all the spectral features are due to the vibrations of the hydroxyl ion. Only two groups of bands are noticed in the region $1300-1800 \mathrm{~nm}$. These are 7460 to $6330 \mathrm{~cm}^{-1}$ and 5880 to $5680 \mathrm{~cm}^{-1}$. Whenever water is present in any compound, in general, two characteristic bands appear around $7000 \mathrm{~cm}^{-1}$ due to $2 v_{3}$ and 5200 $\mathrm{cm}^{-1}$ due to $\left(v_{2}+v_{3}\right)$. The first overtone and combinations of the stretching modes produce the numerous relatively sharp features centered at $6770 \mathrm{~cm}^{-1}$ and the combination of the stretching and bending modes produce the feature near $4350 \mathrm{~cm}^{-1}$. When the bands are broad, it indicates that water molecules are relatively disordered and when the bands are sharp, it indicates that water molecules are located in well defined ordered sites [14]. The band observed at $5675 \mathrm{~cm}^{-1}$ is identified as $v_{3}$ mode of $\mathrm{H}_{2} \mathrm{O}$ molecule. The maximum intense sharp band is at $4740 \mathrm{~cm}^{-1}$ and another sharp band is at $5170 \mathrm{~cm}^{-1}$ which are due to $\mathrm{H}-\mathrm{O}-\mathrm{H}$ bending and asymmetric OH stretching respectively. A very sharp band centered at $4330 \mathrm{~cm}^{-1}$ with shoulders on either side with almost equal intensity is noticed in this range. This band is assigned to the combination of $\mathrm{OH}$ stretching and $\mathrm{Fe}-\mathrm{OH}$ vibration. The low wave number band near $4050 \mathrm{~cm}^{-1}$ may be attributed to Fe-OH units [15].

\section{Conclusions}

1) XRD results indicated that the bauxite (gibbsite phase) had distorted octahedral crystal structure with lattice constants $\mathrm{a}=8.75 \AA, \mathrm{b}=5.075 \AA$, and $\mathrm{c}=9.65 \AA$.

2) EPR results indicated that the bauxite (gibbsite phase) consisted of $\mathrm{Fe}^{3+}$ ion which was in higher concentration.

3) Optical absorption spectrum was characterized by the $\mathrm{Fe}^{3+}$ in the bauxite (gibbsite), which was in a distorted octahedral structure.

4) NIR results were due to the fundamental vibrations of water and $\mathrm{OH}$ units.

These results are conclusively proving that the metal ion is placed in distorted octahedral environment with oxygen and water ligands.

\section{References}

[1] Deer, W.A., Howie, R.A. and Zussman, J. (1978) An Introduction to the Rock Forming Minerals. ELBS, London, 436443.

[2] Crook, N.P., Hoon, S.R., Taylor, K.G. and Perry, C.T. (2001) Electron Spin Resonance as a High Sensitivity Technique for Environmental Magnetism: Determination of Contamination in Carbonate Sediments. Geophysical Journal, 149, 328-337. http://dx.doi.org/10.1046/j.1365-246X.2002.01647.x

[3] Palmer, S.J. and Frost, R.L. (2012) Characterisation of Bauxite and Seawater Neutralised Bauxite Residue Using XRD and Vibrational Spectroscopic Techniques. Journal of Materials Science, 44, 55-63. http://dx.doi.org/10.1007/s10853-008-3123-y

[4] Tripathi, H.S., Ghosh, A., Halder, M.K., Mukherjee, B. and Maiti, H.S. (2012) Microstructure and Properties of Sintered Mullite Developed from Indian Bauxite. Bulletin of Materials Science, 35, 639-643. http://dx.doi.org/10.1007/s12034-012-0337-z

[5] Gräfe, M., Landers, M., Tappero, R., Klauber, C., Hutomo, G., Gan, B., Grabsch, A., Austin, P. and Davies, I. (2010) A Study on Chemical Leaching of Iron from Red Mud Using Sulphuric Acid. 19th World Congress of Soil Science, Soil Solutions for a Changing World, Brisbane, 1-6 August 2010.

[6] Geological Survey of India, Detailed Information on Bauxite in India (1994).

[7] Ford, W.E. (1944) Dana System of Mineralogy. 7th Edition, Wiley Eastern Ltd., New Delhi.

[8] Cullity, B.D. (1959) Elements of X-Ray Diffraction. Addison-Wesley Publishing Company, Boston.

[9] ChiCaroline, MacGillavry, H. and Rieck G.D., Eds. (1968) International Tables for X-Ray Crystallography Vol. III. Kynoch Press, Birmingham.

[10] Rao, P.S. and Subramanian, S. (1985) Single Crystal E.P.R. Studies of Some First-Row Transition Ions in Hexaimidazole Zinc (II) Dichloride Tetrahydrate. Molecular Physics, 54, 415-427. http://dx.doi.org/10.1080/00268978500100321

[11] Castner, T., Niawell, G.S., Holton, W.C. and Slichter, C.P. (1960) Note on the Paramagnetic Resonance of Iron in Glass. Journal of Chemical Physics, 32, 668. http://dx.doi.org/10.1063/1.1730779

[12] Tanabe, Y. and Sugano, S. (1954) On the Absorption Spectra of Complex Ions. I. Journal of the Physical Society of Japan, 9, 753. http://dx.doi.org/10.1143/JPSJ.9.753

[13] Herzberg, G. (1962) Molecular Spectra and Molecular Structure. Vol.2, Van Nostrand, New York, 167. 
[14] Hunt, G.R. and Salisbury, J.W. (1970) Visible and Near-Infrared Spectra of Minerals and Rocks—I. Silicate Minerals. Modern Geology, 1, 283.

[15] Clark, R.N., King, T.V.V., Kleswa, M., Swayze, Swayze, G. and Vergo, N. (1990) High Spectral Resolution Reflectance Spectroscopy of Minerals. Journal of Geophysical Research, 95, 12653-12680. 